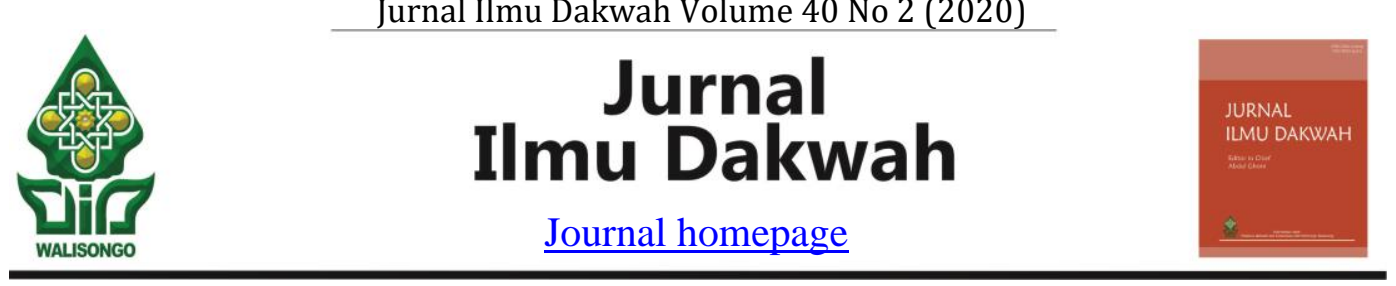

\title{
Program less waste sebagai inovasi dakwah Hanan Attaki
}

\author{
Yasyva Agfa Nizar \\ Universitas Islam Negeri Sunan Ampel Surabaya \\ Email: yasyvag@gmail.com
}

\begin{abstract}
Da'wah about waste reduction is very important considering the problem of waste is still a common problem whose solution has not been resolved. However, not many preachers carry out preaching on the theme of the environment, especially waste reduction. Hanan Attaki as a young preacher who has many followers innovates da'wah by campaigning for a less waste program as a material for da'wah. This paper is a case study on the da'wah carried out by Hanan Attaki in the Bandung youth community. This paper discusses two things, first about the da'wah innovation conveyed by Hanan Attaki to youths to overcome the waste problem in the city of Bandung, second about the process of the less waste program capable of maximizing the role of youth. The author uses Al-Bayanuni's opinion in the book Al-Madkhal Ila Ilmi Dakwah in analyzing. The results of the study show that Hanan Attaki's innovation in preaching by creating a less waste program is the first step in the application of the material presented to the youth of Bandung. Less waste is used as a new lifestyle for Bandung youth. The youth are taught how to minimize and manage organic and inorganic waste. Thus, the less waste program can make Bandung youths involved in taking part in environmental issues as well as addressing them directly, as well as being able to change the style of youth who like to hang out in cafes to hang out in mosques.
\end{abstract}

Keyword : Da'wah inovation; Less Waste; Youth

\begin{abstract}
Abstrak
Dakwah tentang pengurangan sampah sangat penting dilakukan mengingat persoalan sampah masih menjadi problem bersama yang belum terselesaikan solusinya. Namun, tidak banyak para pendakwah yang melakukan dakwah dengan tema lingkungan, pengurangan sampah khususnya. Hanan Attaki sebagai pendakwah muda yang memiliki banyak pengikut, melakukan inovasi dakwah dengan mengkampanyekan program less waste sebagai materi dakwah. Tulisan ini merupakan studi kasus pada dakwah yang dilakukan Hanan Attaki di komunitas pemuda Bandung. Tulisan ini membahas tentang dua hal, pertama tentang inovasi dakwah yang disampaikan oleh Hanan Attaki kepada para pemuda untuk menanggulangi permasalahan sampah di kota Bandung, kedua tentang proses program less waste mampu memaksimalkan peran pemuda. Penulis menggunakan
\end{abstract}


pendapat Al-Bayanuni dalam kitab Al-Madkhal Ila Ilmi Dakwah dalam menganalisis. Hasil studi menunjukkan bahwa inovasi dakwah Hanan Attaki dilakukan dengan membuat program less waste merupakan tindakan awal dalam pengaplikasian materi yang disampaikan kepada pemuda kota Bandung. Less waste dijadikan sebagai gaya hidup baru bagi para pemuda Bandung. Para pemuda diajarkan cara meminimalisir dan mengelola sampah organik dan anorganik. Sehingga, program less waste dapat membuat pemuda Bandung terlibat mengambil peran dalam isu lingkungan sekaligus mengatasinya secara langsung, serta mampu mengubah gaya pemuda yang suka nongkrong di cafe menjadi nongkrong di masjid.

\section{Kata Kunci : Inovasi Dakwah; Less Waste; Pemuda}

\section{PENDAHULUAN}

Sampah masih menjadi persoalan bersama di bidang lingkungan. Membicarakan sampah merupakan hal yang tidak menyenangkan karena persepsi masyarakat umum tentang sampah adalah sesuatu yang sudah tidak mempunyai nilai lagi serta tidak memiliki kebermanfatan bagi masyarakat. Ini merupakan pola pikir umum masyarakat yang belum memiliki kesadaran tentang pentingnya zero waste dan pengelolaan sampah yang baik dan benar. Meningkatnya jumlah sampah saat ini disebabkan oleh tingkat populasi dan standar gaya hidup, yaitu semakin maju dan sejahtera kehidupan seseorang maka semakin tinggi jumlah sampah yang dihasilkan (Haggar, 2007). Peningkatan jumlah sampah yang terjadi disebabkan oleh bertambahnya masyarakat yang berbanding lurus dengan penikatan jumlah konsumsi masyarakat. Sedikitnya tempat pembuangan akhir (TPA) untuk sampah yang ada di kota besar karena lahan terbuka telah berganti menjadi tumpukan beton yang tersusun vertical dan menjulang tinggi ke langit. Oleh karena itu umur tempat pembuangan akhir (TPA) di kota besar berusia pendek karena ketidakmampuannya menampung sampah yang silih berganti berdatangan yang semakin lama semakin menumpuk menjadi suatu pemandangan yang kurang elok yang biasa disebut "gunung sampah".

Setiap hari Kota Bandung, sebagai salah satu kota besar di Indonesia, turut menyumbang produksi sampah yang jumlahnya tidak sedikit. Data dari Perusahaan Daerah (PD) Kebersihan Kota Bandung, Kota Bandung memiliki 2.5 juta jiwa penduduk yang setiap harinya menghasilkan 1500 sampai 1600 ton sampah. Dari jumlah ini, 48\% adalah sampah non organik yang memiliki waktu panjang untuk terurai (Witarsa, 2019). Dengan keadaan seperti ini, dikhawatirkan TPA (Tempat Pembuangan Akhir) yang menjadi muara sampahsampah tersebut tidak akan bisa menampung lagi. Pemerintah Bandung telah mengupayakan untuk mengurangi produksi sampah salah satunya meluncurkan program Kang Pisman. Gerakan Kang Pisman yang telah dicanangkan oleh pemerintah kota Bandung pada tahun 2018 silam mendapatkan antusias yang positif dari warga kota Bandung. Kang Pisman sendiri merupakan singkatan dari Kang (kurangi) Pis (pisahkan) Man (manfaatkan) sampah. Gerakan ini merupakan kolaborasi dengan antara pemerintah, warga, swasta, dan lainnya dalam membangun peradaban baru dalam pengelolaan sampah yang lebih maju (Istiqomah dan Maharani, 2018).

Konsep pengelolaan sampah 3R sudah tidak asing lagi di telinga masyarakat. Konsep ini sangat cocok diterapkan di negara berkembang yang karena keterbatasan teknologi maka harus memberdayakan masyarakat sebagai pelaku yang menghasilkan sampah. 
Namun, pada kenyataannya penerapan 3R dalam kehidupan sehari-hari masih jauh dari yang diharapkan. Prinsip Reduce, Reuse, Recycle (3R) yang menjadi ujung tombak dalam menangani sampah di lingkungan masyarakat seakan hanya slogan yang tidak mengena (Widiarti, 2012).

Dalam hal ini pemerintah kota Bandung mendesak dilakukan karena generasi muda memegang peran penting dalam mengatasi sampah. "Generasi muda memegang peranan yang signifikan dalam upaya memerangi sampah. Pemuda hanya 5,6 \% yang memilah sampah, kemudian sebanyak $19 \%$ pemuda kadang memilah sampah yang ada, namun terkadang tidak memilah sampah dan langsung membuangnya. Bahkan, sebanyak $75 \%$ pemuda tidak pernah memilah sampah, main buang-buang saja. Data saat ini sebanyak 64 \% sampah masih berakhir di pembuangan akhir. Hanya sekitar 0,6\% sampah yang didaur ulang dan sebanyak 1,1 \% yang dibuat menjadi kompos. Sejumlah Inovasi Secara khusus mengapresiasi sejumlah inovasi yang telah dilakukan Pemerintah Kota Bandung untuk meningkatkan kesadaran warga akan pentingnya menjaga kebersihan (Raharjo, 2018).

Peran generasi muda di kota Bandung diharapkan oleh walikota dapat menjadi titik yang strategis bagi penanggulangan sampah di kota Bandung. Generasi muda diharapkan berperan aktif dalam berbagai kegiatan yang positif dalam mengembangkan kemampuan, keberaniannya dalam melakukan aksi-aksi yang bernilai dan bermanfaat bagi lingkungan. Peran generasi muda selalu sentral dalam perubahan, mengingat dalam jiwa pemuda selalu ada hasrat yang dinamis. Ciri khas dari seseorang muda adalah semangatnya yang menyalanyala, bahkan terkadang kurang memiliki perhitungan. Selain itu, pemuda juga secara fisik lebih kuat dibandigkan dengan usia-usia di atasnya, sehingga tidaklah berlebihan jika dikatakan bahwa usia muda adalah usia yang paling produktif dalam diri manusia (Syamsudin, 2008).

Namun, anak muda belum banyak mengambil peran dalam penanganan sampah, begitu pula dengan seorang pendakwah. Tidak banyak tokoh agama menjadikan sampah sebagai salah satu materi dari ceramah atau gerakannya dalam mengajak masyarakat. Hadirnya Hanan Attaki, seorang pemuda sekaligus pendakwah, yang peduli dengan isu lingkungan, dengan menggunakan otoritasnya sebagai seorang pendakwah, merupakan langkah yang baik. Hanan Attaki bersama dengan jama'ahnya yang notabene pemuda menggagas suatu program yang bernama less waste.

Kajian-kajian yang disampaikan oleh Hanan Attaki sangat mudah dimengerti dan ringan sehingga banyak masyarakat khususnya para pemuda kota Bandung yang tertarik dan berminat dalam melakukan aksi gaya hidup less waste. Pengelolaan sampah yang dilakukan oleh Ustadz Hanan Attaki berbasis di masjid Al-Lathif kota Bandung. Pengelolaan sampah tersebut dilakukan secara sistematis, masif dan terarah sesuai dengan kaidah ajaran agama Islam.

Less waste pada dasarnya bukanlah pengelolaan dengan konsep sama sekali tidak ada sampah, mengingat tidak ada aktivitas manusia yang tidak menghasilkan sampah. Konsep ini menekankan pada upaya pengurangan hingga nol jumlah sampah yang masuk ke Tempat Pembuangan Akhir (TPA). Oleh karena itu penelitian ini fokus pada dua hal, pertama tentang inovasi dakwah yang disampaikan oleh Hanan Attaki kepada para pemuda untuk 
menanggulangi permasalahan sampah di kota Bandung, kedua tentang proses program less waste mampu memaksimalkan peran pemuda.

Terdapat beberapa penelitian sebelumnya yang membahas tentang pengurangan sampah dan pengelolaan sampah yang melibatkan masyarakat atau komunitas. Di antaranya yaitu, pertama, penelitian yang dilakukan oleh Ahmad Faqih (2015) tentang penguatan kapasitas mahasiswa peduli sampah. Penelitian ini merupakan hasil pendampingan mahasiswa Prodi Pengembangan Masyarakat Islam Fakultas Dakwah dan Komunikasi UIN Walisongo Semarang. Melalui penelitian ini Faqih memiliki 3 tujuan yaitu, meningkatkan pengetahuan mahasiswa Prodi PMI tentang sistem pengolahan sampah di lingkungan kampus, kedua menumbuhkan kesadaran dan kepedulian mahasiswa pada persoalan sampah di lingkungan kampus, dan ketiga menumbuhkan kesadaran mahasiswa secara individu dan kolektif dalam melaksanakan aksi pengolahan sampah secara bersamasama. Melalui metode PRA (participatory rural appraisal) ini ternyata dapat meningkatkan kapasitas pengetahuan mahasiswa tentang pengolahan sampah. Melalui PRA juga mahasiswa mengalami peningkatan kapasistas berupa transfer of knowledge, transfer of value, dan transfer of skill.

Kedua, penelitian yang dilakukan oleh Hikmahtussa'adah (2018) yang membahas tentang partisipasi masyarakat dalam pengelolaan kebersihan lingkungan melalui program bank sampah di kelurahan Bambankerep Kecamatan Ngaliyan (perspektif dakwah bil hal). Pada penelitian ini berusaha mendeskripsikan tentang partisipasi masyarakat dalam pengelolaan kebersihan lingkungan melalui program bank sampah sebagai bentuk dari implementasi dakwah bil hal, serta dampak partisipasi masyarakat ini dalam pengelolaan kebersihan lingkungan. Dakwah bil hal yang dilakukan dari pengelolaan kebersihan lingkungan terlihat sangat efektif melalui kegiatan PKK, menabung sampah, hingga mampu menghasilkan secara ekonomis. Penulis menggolongkan partisipasi masyarakat dengan sebutan partisipasi aktif. Sehingga, dampak yang dapat dirasakan secara nyata adalah masyarakat telah memiliki kemampuan memilah sampah sesuai dengan jenisnya kemudian mengolahnya. Pengelolaan sampah ini juga mampu memberikan dampak secara ekonomi.

Ketiga, Andi Muhammad Saleh Alwi, dkk (2020) yang melakukan penelitian tentang pelestarian lingkungan sebagai implementasi dakwah bil-hal dan wujud kesadaran masyarakat. Penelitian ini dilakukan di kota Makassar, dengan memfokuskan pada dakwah pelestarian lingkungan dan implementasi nilai-nilai dakwah bil-hal dalam melestarikan lingkungan. Hasil dari penelitian ini menunjukkan bahwa implementasi dakwah bil-hal dapat dilihat dari slogan yang dibuat oleh Pemerintah Kota Makassar yang berbunyi "Makassar Tidak Rantasa (MTR). Slogan ini dinilai sebagai wujud dari komitmen dan program yang berhasil mengubah perilaku masyarakat akan kesadaran menjaga lingkungan.

Keempat, Siti Nurul Yaqinah (2019) melalui penelitian tentang Implementasi dakwah berbasis lingkungan hidup di pondok pesantren Nurul Haramain Narmada Lombok Barat. Kajian dengan menggunakan studi kasus, peneliti mengungkap bahwa dakwah berbasis lingkungan hidup di Pondok Pesantren Nurul Haramain dilakukan melalui dakwah persuasif dalam bentuk dakwah bil-lisan, bil-qalam dan bil-hal. Dakwah partisipatif ini 
dalam bentuk kebijakan pondok pesantren dalam mewujudkan lingkungan bersih, penanaman pohon dan penghijauan, serta gerakan pohon gratis.

Keempat penelitian yang pernah dilakukan tersebut menjadi penting sebagai dasar dalam tulisan ini. Bedanya, dalam tulisan ini fokus kajian tidak hanya dakwah pemberdayaan masyarakat saja, namun posisi seorang da'i sebagai pembawa pesan dakwah juga menjadi fokus kajian, terlebih tentang komunikasi yang dilakukan da'i kepada mad'u.

\section{METODE PENELITIAN}

Penelitian ini termasuk kedalam jenis penelitian deskriptif kualitatif, dengan menggunakan analisa deskriptif pada program less waste sebagai inovasi metode dakwah Hanan Attaki di Bandung. Data primer didapatkan dari wawancara dan observasi, sementara data sekunder didapatkan dari literatur, melalui buku, jurnal ilmiah, skripsi, ebook, berita, media sosial youtube, instagram dan internet. Subjek pada penelitian ini adalah program less waste. Objek yang diteliti adalah inovasi dakwah Hanan Attaki dalam memaksimalkan peran generasi muda di Bandung.

\section{HASIL DAN PEMBAHASAN}

\subsection{Dasar - dasar metode dakwah}

Metode dakwah memiliki dua suku kata yakni kata Metode dan Dakwah. Dari segi bahasa metode berasal dari dua kata yaitu "meta" (melalui) dan "hodos" (jalan, cara). Metode adalah cara atau jalan yang harus dilalui untuk mencapai suatu tujuan. Munir (2009), bahkan menyebutkan bahwa metode berasal dari bahasa Jerman dan Yunani. Dalam bahasa Jerman, metode berasal dari kata methodica yang artinya ajaran tentang metode. Dalam bahasa Yunani metode berasal dari kata methodos artinya jalan, yang dalam bahasa Arab disebut thariq. Dalam kamus ilmiah popular metode juga dapat diartikan sebagai cara yang sistematis dan tertatur untuk melaksanakan sesuatu atau cara kerja (Partanto dan Barri, 1994).

Pengertian metode secara istilah adalah jalan yang kita lalui untuk mencapai tujuan. Banyak usaha yang tidak dapat berhasil atau pasti tidak membuahkan hasil optimal, kalau tidak dipakai cara yang tepat (Bertens, 2005). Metode juga dapat diartikan sebagai suatu cara atau teknis yang dilakukan dalam proses penelitian (Mardalis, 1995).

Sedangkan, istilah dakwah sudah tidak asing lagi, bahkan istilah ini dapat dikatakan popular di kalangan masyarakat. Namun demikian yang sering kita jumpai sekarang bahwa istilah dakwah oleh kebanyakan orang diartikan hanya sebatas pengajian, ceramah, khutbah, atau mimbar seperti halnya yang dilakukan oleh para mubaligh, ustaz, atau khatib. Dakwah sering diartikan sebagai sekedar ceramah dalam arti sempit. Kesalahan ini sebenarnya sudah sering diungkapkan, akan tetapi di dalam pelaksanaannya tetap saja terjadi penciutan makna (Hafidhuddin, 1998).

Oleh karena itu, istilah dakwah perlu dipertegas lagi dalam pengertiannya. Secara harfiah dakwah merupakan masdar dari fi'il da'a dengan arti ajakan, seruan, panggilan, undangan. Seperti yang terdapat pada surat An-Nahl ayat 125 (Amin, 2009). 
Metode dakwah yang digunakan harus sesuai dengan situasi dan kondisi mad'u sebagai penerima pesan-pesan dakwah. Suatu pesan walaupun baik, tetapi disampaikan dengan menggunakan metode yang tidak tepat, maka pesan tersebut bisa ditolak oleh penerima pesan (Syukir, 1983). Dengan begitu, dapat dipahami bahwa metode dakwah merupakan sebuah pendekatan komunikatif dialogis yang dilakukan oleh seorang da'i (komunikator) kepada mad'u untuk mencapai suatu tujuan atas dasar hikmah dan kasih sayang. Hal ini mengandung arti bahwa pendekatan dakwah harus bertumpu pada suatu pandangan human oriented menempatkan penghargaan yang mulia atas diri manusia (Saputra, 2011).

Al-Bayanuni (2001)membagi metode dakwah menjadi empat yakni, Uslub bi al Hikmah, Uslub Mau'izah Hasanah, Mujadalah bi al-lati hiya Ahsan, al-Qudwah al-Hasanah. Metode Uslub bi al Hikmah diartikan cara mendapatkan kebenaran dengan ilmu dan akal. Adapun yang dimaksud dengan hikmah dari Allah. SWT adalah mengetahui sesuatu dan menemukan sesuautu tersebut dalam tujuan utama dari penetapan hukum, mengetahui segala yang ada dan mengatahui segala bentuk kebaikan.

Hikmah menurut bahasa, menurut Bayanuni, bisa digunakan dalam beberapa makna. Di antaranya adalah keadilan, ilmu, kebijaksanaan, kenabian, Al Qur'an, Injil, Sunnah dan beberapa penggunaan lainnya. Hikmah juga digunakan bagi sesuatu yang lafalnya sedikit sedangkan maknanya besar. Seseorang dikatakan bijaksana apabila ia telah dihadapkan kepada berbagai permasalahan sehingga membuatnya menjadi tangguh. Pemilihan metode yang sesuai untuk dijalankan pada kondisi yang sesuai dan keadaan tertentu.

Metode yang kedua yakni Uslub Mau'izah Hasanah (nasehat yang baik). Al-Mau'izhah menurut bahasa diambil dari wa'azhahu, ya'izhuhu, wa'zhun, wa'izhah yang diartikan sebagai menasehatinya, memperingatkannya dengan hukuman-hukuman dan memerintahkannya serta mewasiatkannya melakukan keta'atan. Al-Hasanah merupakan kebalikan dari al-sayyi ah (keburukan). Nasehat terkadang ada yang bersifat baik dan terkadang ada yang bersifat buruk. Ini dilihat dari objek nasehat dan perintah tersebut dan tergantung juga pada cara yang digunakan penasehat.

Metode yang ketiga yakni Mujadalah bi al-lati hiya Ahsan. Menurut bahasa almujadalah diambil dari jadalahu, mujadalah dan jidalan yang artinya mendebatnya dan memusuhinya. Perdebatan adalah ambisi dalam permusuhan serta kesanggupan untuk itu. Ia juga diartikan permusuhan yang bersangatan. Dalam hadis disebutkan, "Tidaklah suatu kaum berdebat kecuali mereka dalam kesesatan." Debat juga diartikan menentang dalil dengan dalil dan mujadalah adalah berdebat dan saling bermusuhan. Sedangkan menurut istilah ulama mendefinisikannya dengan beberapa pengertian yang saling berdekatan. Di antaranya adalah: "Sebuah ibarat dalam perlawanan seseorang terhadap lawannya dengan menjelaskan ketidakbenaran perkataannya dengan dalil yang kuat atau tidak (Al-Bayanuni, 2001).

Metode yang keempat yakni al-Qudwah al-Hasanah. Al-Qudwah menurut bahasa adalah aluswah atau tauladan. Qudwah di sini diikat dengan al-hasanah (yang baik) agar tidak masuk kedalamnya tauladan yang buruk. Terkadang seseorang menjadi tauladan yang baik atau tauladan yang buruk. Tauladan yang baik dibedakan menjadi dua bagian. Pertama, Tauladan baik yang mutlak, yaitu yang terbebas dari kesalahan dan kehinaan sebagaimana 
yang terdapat pada diri para Nabi dan Rasul. Kedua, Tauladan baik yang diikat dengan sesuatu yang disyariatkan Allah. Sebagaimana yang terdapat pada orang-orang saleh dan orang-orang yang bertakwa di antara hamba Allah dan mereka bukanlah para Nabi dan rasul (Al-Bayanuni, 2001).

\subsection{Kegiatan Dakwah Hanan Attaki}

Hanan Attaki merupakan seorang pendakwah yang cukup digandrungi oleh masyarakat, terutama generasi muda. Secara keilmuan agama, Hanan Attaki sangat mumpuni, ia pernah sekolah di Pondok Pesantren Ruhul Islam Banda Aceh, Universitas alAzhar Mesir hingga memperoleh gelar Lc, hingga mendapatkan penghargaan menjadi qori terbaik versi Fajar TV, di Kairo pada tahun 2005 (Pariska, 2018).

Hanan Attaki semakin dikenal publik lantaran cara dakwahnya yang santai dan mampu merangkul semua kalangan, khususnya generasi muda. Tema dakwah kekinian serta metode yang merangkul menjadi ciri khas dakwah Hanan Attaki (Pariska, 2018). Gaya ceramah yang gahul, gaya berbusana khas anak muda, pakaian 'dinas' Hanan Attaki saat berceramah ini tak terlihat seperti ustaz kebanyakan. Isi ceramahnya pun banyak menyangkut hal-hal ringan, seperti tentang rezeki, niat, doa, kesabaran, dan jodoh. Tema seperti ini dinilai mampu menarik generasi muda karena bahasa penyampaian yang mudah dimengerti (Elmira, 2019).

Sejak 2015, Hanan Attaki telah berdakwah melalui Gerakan Pemuda Hijrah, baik melalui akun YouTube maupun vlog. Selain itu, ada juga "Shift", sebuah gerakan mengajak lebih banyak generasi muda untuk belajar agama Islam. Uniknya, banyak anggotanya dari kalangan anak muda yang memiliki hobi main skateboard, sepeda BMX, serta surfing. Dalam Shift, dibangun banyak kegiatan yang dikelola, seperti Ladies Day, Shift Ngabuburide, Teras Tahfidz, Voice of Youth, dan Shift Weekend. Melalui tagline di akun instagramnya, kampanye "Banyak main, banyak manfaat, banyak pahala, sedikit dosa" membuat banyak anak muda yang menyukai dakwah kekinian yang dibawakan Hanan Attaki (Elmira, 2019).

\subsection{Gerakan Less waste sebagai inovasi Dakwah}

Less waste pada dasarnya tidak berbeda dengan zero waste. Konsep dasar dari less waste sendiri adalah pengelolaan sampah dengan melakukan pemilahan, pengomposan dan pengumpulan barang layak jual (Ika, 2000). Perspektif akan keseimbangan alam yang berkaitan dengan menjamurnya sampah plastik menghasilkan sebuah konsep less waste yang berdasarkan pada pemilahan untuk prioritas atau main idea. Zero waste atau less waste, merupakan dua istilah yang sering digunakan pejuang sampah. (Johnson, 2013). Konsep ini justru mengedepankan upaya pengurangan sampah sejak awal, yaitu menolak dan mengurangi hal yang tidak esensial, dan menggunakan kembali apa yang bisa digunakan.

Sebagian orang yang lain melihat kegiatan ini merasa pesimis, karena kegiatan tersebut tidak akan menghentikan produksi sampah, mengingat tetap ada industri yang menghasilkan sampah. Tidak semua produk dapat didaur ulang dan sistem pengelolaan sampah di sektor industri belum memiliki kesiapan. Di sisi lain, konsep less waste memiliki 
kesan modest, yaitu prinsip untuk mengurangi sampah yang dihasilkan setiap hari (Hanifa, 2019).

Pada mulanya, keresahan sampah di Bandung terjadi karena peningkatan volume sampah yang terus bertambah setiap tahunnya. Oleh karena itu, Hanan Attaki memilih memperhatikan upaya menjaga lingkungan, khususnya tentang sampah. Kegiatan dakwah dilakukan di masjid Al-Lahief dan masjid Trasns Studio Bandung. Pada Oktober tahun 2019, ceramah Hanan Attaki dipublikasi di media sosial youtube berisi tentang ajakan kepada para generasi muda untuk melakukan trend baru yakni less waste yang berbasis di masjid. Isu tentang less waste ini tidak hanya perlu dikampanyekan melalui media saja, namun juga membutuhkan support dan kampanye lebih luas, salahsatunya dilakukan dari masjid. Karena nilai kebaikan dalam menjaga lingkungan ini tidak bisa dilepaskan dari ajaran agama Islam.

Hanan Attaki meminjam istilah "sedekah sampah" dari orang-orang yang terlebih dahulu memulai gerakan zero waste, dengan menggunakan masjid sebagai pusat kampanye diharapkan masjid tidak hanya sebagai tempat ibadah secara vertikal kepada Allah semata, namun menjadi pusat solusi masalah duniawi, seperti masalah lingkungan. Masjid memiliki otoritas sebagai salah satu tempat ibadah yang dianggap suci oleh umat Iislam, sehingga hal-hal yang dibahas di dalam masjid akan memberikan kekuatan. Ketika isu lingkungan diangkat oleh para pendakwah dengan menggunakan narasi agama, Al-Qur'an dan Hadist, diharapkan kepercayaan publik terhadap isu lingkungan meningkat, pada akhirnya banyak generasi muda yang ikut serta dalam mengelola dan mengikuti trend less waste.

Dibentuknya program less waste di masjid, menjadikan masjid sebagai tempat pengumpulan sampah, baik itu sampah yang siap di recycle (daur ulang) ataupun sampah anorganik lainnya. Para pemuda dibekali secara teknis tentang cara mengumpulkan sampah di masjid yang tidak "nyampah", mengumpulkan sampah yang tidak bau, dan mengumpulkan sampah yang siap di daur ulang, sehingga masjid tidak akan kotor karena adanya sampah yang terkumpul.

Program less waste ini secara tidak langsung telah berkontribusi dalam membantu kinerja petugas kebersihan. Masjid dijadikan sebagai tempat operasional para petugas kebersihan. Hasil dari pengumpulan sampah ini bernilai secara ekonomi tidak hanya untuk merenovasi masjid akan tetapi diperuntukkan juga bagi para petugas sampah. Dengan adanya program less waste ini setidaknya petugas kebersihan diberdayakan dengan penambahan upah. Para petugas kebersihan dapat mendatangi masjid, kemudian mengambil sampah yang masih memiliki nilai ekonomis sehingga dapat dijual kembali ke pengepul.

\subsection{Less waste dan upaya memaksimalkan peran pemuda}

Substansi peran tidak dapat terlepas dari motif dan kebiasaan dari individu. Soerjono Soekanto, mengartikan peran sebagai aspek dinamis suatu kedudukan (status). Apabila seseorang melaksanakan hak dan kewajibannya sesuai dengan kedudukannya, maka ia menjalankan suatu peranan. Hakekatnya peran juga dapat dirumuskan sebagai suatu rangkaian perilaku tertentu yang ditimbulkan oleh suatu jabatan tertentu. Kepribadian seseorang juga mempengaruhi bagaimana peran itu harus dijalankan. Peran yang 
dimainkan pada hakekatnya tidak ada perbedaan, baik yang dimainkan/diperankan pimpinan tingkat atas, menengah maupun bawah akan mempunyai peran yang sama (Soekanto, 2002).

Lebih jauh Soekanto menjelaskan bahwa agar dapat disebut sebagai peran, maka harus mencakup tiga syarat, yaitu pertama, peran meliputi norma-norma yang dihubungkan dengan posisi atau tempat seseorang dalam masyarakat. Peranan dalam arti ini merupakan rangkaian peraturan-peraturan yang membimbing seseorang dalam kehidupan kemasyarakatan. Kedua, peran merupakan suatu konsep perilaku apa yang dapat dilaksanakan oleh individu-individu dalam masyarakat sebagai organisasi. Peran juga dapat dikatakan sebagai perilaku individu, yang penting bagi struktur sosial masyarakat. Ketiga, peran merupakan suatu rangkaian yang teratur yang ditimbulkan karena suatu jabatan. Manusia sebagai makhluk sosial memiliki kecenderungan untuk hidup berkelompok. Dalam kehidupan berkelompok akan terjadi interaksi antara anggota masyarakat yang satu dengan anggota masyarakat lainnya. Tumbuhnya interaksi diantara mereka ada saling ketergantungan dan muncul apa yang dinamakan peran (role) (Soekanto, 2009).

Pemuda merupakan individu yang bila dilihat secara fisik maupun psikis sedang mengalami perkembangan, sehingga pemuda merupakan sumber daya bagi pembangunan, baik saat ini maupun nanti yang akan menggantikan generasi sebelumnya. Melalui karakternya yang dinamis, pemuda bahkan sering bergejolak dan optimistik, namun belum memiliki pengendalian emosi yang stabil (Abdullah, 1974).

Pemuda dapat dibagi ke dalam tiga perspektif, yakni pemuda sebagai generasi, pemuda sebagai transisi, dan pemuda sebagai pencipta dan konsumen budaya. Pertama, pemuda dalam pendekatan generasi mengingatkan kita bahwa setiap generasi pemuda memiliki sisi historis dan konteksnya masing-masing.

Kedua, pemuda sebagai transisi, dianggap sebagai pendekatan deterministik yang meyakini bahwa pemuda mengalami tahapan kehidupan yang bersifat tetap dan universal (Azca dkk. 2014). Pandangan ini selaras dengan konsep fungsionalisme yang menegaskan berbagi peran untuk mewujudkan keseimbangan. Pandangan tersebut telah menciptakan argumentasi bahwa transisi pemuda yang menekankan pada asusmsi biologis dan psikososial terhadap perkembangan kemudian berakibat pada ketergantungan legitimasi dan intervensi kaum dewasa untuk memastikan bahwa kaum muda melewati jalur yang sesuai dengan yang konstruksi dan definisi yang telah dilampaui sebelumnya oleh kaum dewasa (Sumantri, dkk, 2008).

Ketiga, pemuda sebagai pencipta dan konsumen budaya. Nilan (2006) menjelaskan mengenai interaksi antara budaya lokal dan global, sehingga memunculkan budaya hybrid di antara pemuda muslim di Indonesia. Hal ini juga sebagai bagian dari strategi kaum muda untuk menghadapi derasnya arus globalisasi, sekaligus menunjukkan bahwa mereka mampu menjadi agensi budaya yang memilah dan memilih secara kritis. Ketiga pandangan tersebut menegaskan dinamika pemuda dalam merespon perubahan.

Langakah awal yang dilakukan oleh Hanan Attaki melalui pemuda hijrah dengan mengajak para pemuda kota Bandung melakukan sosialisasi tentang gerakan less waste serta menerapkan gaya hidup zero waste, kemudian Shift Pemuda Hijrah mengarahkan cara memisahkan sampah yang baik dan benar, agar sampah tidak lagi dicampur antara organik 
dan anorganik. Selanjutnya, memisahkan minimal tiga jenis sampah anorganik yaitu kertas, kardus dan botol plastik. Untuk simulasi pertama program less waste hanya dibuka pendaftaran dua ratus orang sebagai member untuk menjalankan sistem less waste dan sedekah sampah.

Pembudayaan trend less waste pada pemuda di Bandung kemudian diperkuat lagi dengan gerakan kajian starterkit. Starterkit merupakan perlengkapan yang disiapkan dan dibawa oleh para jama'ah pada saat mengikuti kajian Hanan Attaki, yaitu pertama, membawa botol tumbler dari rumah bagi yang sudah punya. Shift Pemuda Hijrah juga menyediakan dan menjual merchandise botol tumbler. Teknisnya setiap jama'ah membawa botol tumbler dan pergi ke masjid tempat kajian, yaitu di masjid al-Lathief atau masjid Trans Studio Bandung. Setibanya di masjid, pihak Shift dan Pemuda Hijrah menyediakan refiil air isi ulang. Langkah itu dipergunakan dalam rangka mengurangi dan meminimalisir penggunaan botol plastik.

Kedua, perlengkepan yang dibawa dalam kajian starterkit yakni buku catatan, yang berfungsi untuk resume atau mencatat hal-hal penting yang disampaikan dalam kajian. Resume ini sangat berguna untuk dipelajari dan dipahami, hal ini juga bertujuan agar nilainilai yang disampaikan dalam kajian terekam dengan baik melalui catatan.

Ketiga, dalam gerakan less waste ini para jama'ah membawa sampah anorganik seperti kadus, kertas, koran dan botol plastik. Sampah-sampah ini akan dikelola pihak Pemuda Hijrah untuk didaur ulang dan dimanfaatkan untuk kepentingan bersama.

\subsection{Analisa Inovasi dakwah Hanan Attaki menggunakan Kitab al-Bayanuni}

Inovasi dakwah yang dilakukan Hanan Attaki sangat menarik jika dikaitkan dengan metode dakwah menurut Al-Bayanuni dalam kitab Al madkhal ila ilmi Dakwah. Inovasi dakwah yang dilakukan Hanan Attaki sebenarnya telah menggunakan beberapa metode, yakni metode Uslub bi al Hikmah, Uslub Mau'izhah Hasanah (nasehat yang baik), dan alQudwah al-Hasanah (tauladan yang baik).

Metode uslub bi al hikmah diartikan sebagai metode yang menggunakan kebijaksanaan, akal, ilmu, Al-Qur'an dan Hadist. Melalui inovasi yang dilakukan, Hanan Attaki telah mampu menentukan prioritas, mendahulukan yang lebih penting dari yang penting. Metode dakwah tidaklah dianggap sebagai metode yang baik dan bijaksana jika tidak mampu menentukan skala prioritas dalam dakwah.

Tiga hal yang menjadi tiang dakwah dengan hikmah, yakni ilmu, kesatuan, dan kedewasaan berpikir. Dakwah hikmah dengan ilmu berarti mengerti tentang seluk-beluk syariat dan dasar-dasar keimanan di samping perlu juga memahami ilmu-ilmu inovasi yang dapat memperdalam keimanan mad'u (pemuda kota Bandung). Dengan adanya pengetauhan dan wawasan yang luas sebagai da'i dapat membantu memahami kondisi mad'u dengan berbagai pertimbangan tipologi dan karakteristik masyarakat pemuda Bandung. Dakwah dilakukan dengan kedewasaan berpikir, menghendaki pendekatan yang matang dalam menyampaikan dakwah, dan tidak tergesa-gesa, hal ini dinterpretasikan Hanan Attaki dalam merancang program less waste.

Jika dikaitkan dengan metode dakwah Uslub Mau'izhah Hasanah, yakni nasehat yang baik, dapat diimplementasikan melalui tutur kata yang lembut dan sopan. Dakwah yang 
dilakukan Hanan Attaki selalu memerhatikan tutur kata yang sesuai dengan kondisi mad'unya, dengan cara memberikan nasihat yang baik kepada orang lain dengan cara yang baik, memberikan petunjuk-petunjuk ke arah kebaikan dengan bahasa yang baik, dapat diterima, dan berkenan dihati, sehingga pemuda yang menjadi objek dakwah dengan rela hati dan atas kesadarannya sendiri dapat mengikuti ajaran yang disampaikan.

Mau'izhah Hasanah diinterpretasikan dalam makna proses seorang da'i dalam berinteraksi dengan mad'u melalui pendekatan verbal maupun non verbal, dengan nasehat yang yang diberikan tidak m unsur menyakiti perasaan batin seseorang. Dengan metode mauidzah Hasanah Hanan Attaki menciptakan lifestyle "nongkrong" di masjid menjadi trend baru bagi pemuda Bandung. Sebelumnya, para pemuda jarang melangkahkan kaki ke masjid untuk menghadiri pengajian dan taklim, pemuda lebih memilih bermain game di rumah, atau berkumpul dengan teman-teman sebaya di cafe. Program less waste benar-benar menjadi alternatif syiar Hanan Attaki dalam mengayomi dan merangkul pemuda Bandung dalam berkegiatan positif dan dapat menjadi sebuah trend baru di kalangan anak muda. Trend ini dapat membuat persepsi positif di kalangan anak muda untuk semakin giat mengikuti berbagai kajian dalam mengais pegetauhan dan wawasan dunia Islam.

Jika dikaitkan dengan metode dakwah al-Qudwah al-Hasanah (tauladan yang baik), Hanan Attaki tidak hanya menyampaikan materi fikih, akidah, akhlak dan syariat saja, tetapi materi tersebut sekaligus diaplikasikan melalui tindakan, dengan dibuatnya program less waste yang bertujuan mengurangi sampah dan meminimialisir pemakaian barang yang berbahan plastik. Pemuda Bandung sangat antusias dalam merespon program less waste, dikarenakan program ini dinilai inovatif, menarik dan mudah dilakukan oleh pemuda kota Bandung. Langkah sederhana ini akan memunculkan lifestyle dan social standart baru dalam membuat kajian dakwah.

\section{KESIMPULAN}

Berdasarkan penjelasan di atas maka dapat disimpulakn bahwa inovasi dakwah ustadz Hanan Attaki dalam membuat program less waste ini merupakan tindakan awal dalam pengaplikasian materi yang disampaikan kepada pemuda kota Bandung. Less waste dijadikan sebagai gaya hidup baru bagi para pemuda di Bandung. Para pemuda diajarkan cara meminimalisir dan mengelola sampah organik dan anorganik sehingga dapat dimanfaatkan kembali atau disedekahkan kepada masyarakat yang lebih membutuhkan. Gaya bahasa kekinian yang dimiliki oleh ustadz Hanan Attaki merupakan salah satu faktor pemikat para pemuda Bandung yang dulunya "nonkrong" di kafe menjadi beralih di masjid. Sehingga, program less waste dapat membuat pemuda Bandung terlibat mengambil peran dalam isu lingkungan sekaligus mengatasinya.

\section{DAFTAR PUSTAKA}

\section{Buku}

Abdullah, T. (1974). Pemuda dan perubahan sosial. Jakarta: LP3ES.

Al-Bayanuni, M. (2001). al-Madkhal ila 'ilm al-Dakwah. Beirut: Muassasah al-Risalah. Amin, S.M. (2009). Ilmu Dakwah. Jakarta: Amzah. 
Azca, N. dkk. (2014). Buku Panduan Studi Kepemudaan, Teori Metodologi, dan Isu-isu Kontemporer. Yogyakarta: PMPS YouSure-Kemenpora RI.

Bertens, K. (2005). Metode Belajar Untuk Mahasiswa. Jakarta: Gramedia Pustaka Utama.

Hafidhuddin, D. (1998). Dakwah Aktual. Jakarta: Gema Insani Press.

Haggar, E.S. (2007). Sustainable Industrial Design and Waste Management. United States of America: Elsevier Academic Press.

Johnson, B. (2013). Zero Waste Home: The Ultimate Guide to Simplify Your Life by Reducing Your Waste. France: Scribner.

Mardalis. (1995). Metode Penelitian Suatu Pendekatan Proposal. Jakarta: Bumi Aksara.

Nilan, P, dan Carlos F. (2006). Global Youth? Hybrid Identities Plural Worlds. London: Routledge.

Partanto, P.A. dan M. D.B. (1994). Kamus Ilmiah Populer. Surabaya: Arloka.

Saputra, W. (2011). Pengantar Ilmu Dakwah. Jakarta: PT. Raja Grafindo Persada.

Soekanto, S. (2002). Teori Peranan. Jakarta: Bumi Aksara.

_-_. (2009). Peranan Sosiologi Suatu Pengantar, Edisi Baru. Jakarta: Rajawali Pers.

Sumantri, E. dkk. (2008). Pembinaan generasi muda, In: Generasi dan generasi muda. Jakarta: Universitas Terbuka.

Syamsudin, A. (2008). Kaum Muda Menatap Masa Depan Indonesia. Jakarta: RM Books.

Syukir, A. (1983). Dasar - dasar Strategi Dakwah Islam. Surabaya: Al-Ikhlas.

\section{Jurnal dan Website}

Alwi, A.M.S, dkk. (2020). "Pelestarian Lingkungan sebagai Implementasi Dakwah bil Hal dan Wujud Kesadaran Masyarakat". Prosiding. OSFPreprints.

Elmira, P. 2019. "Sosok ustaz Hanan Attaki penceramah yang akrab dengan milenial." $\begin{array}{lllll}\text { Liputan } & 6 . c o m . & \text { Diakses } & 27 & \text { Mei }\end{array}$ https://www.liputan6.com/lifestyle/read/3960637/sosok-ustaz-hanan-attakipenceramah-yang-akrab-dengan-milenial

Faqih, A. (2015). "Penguatan Kapasitas Mahasiswa Peduli Sampah (Pendampingan Mahasiswa Prodi Pengembangan Masyarakat Islam Fakultas Dakwah dan Komunikasi UIN Walisongo Semarang". DIMAS. 15 (1) h. 129-144

Hanifa, A.A. (2017). "Zero waste atau Less waste." Cleanomic.co.id. Diakses 25 Mei 2020. https://cleanomic.co.id/zerowaste-atau-lesswaste/

Hikmahtussa'adah. (2018). "Partisipasi Masyarakat dalam Pengelolaan Kebersihan Lingkungan melalui Program Bank Sampah di Kelurahan Bambankerep Kecamatan Ngaliyan (Perspektif Dakwah bil-Hal)". SKRIPSI. Semarang: UIN Walisongo

Ika, D. (2000). "Pengelolaan Sampah Menuju Zero Waste di Kelurahan Kebonmanis Cilacap." Monograph Project. Semarang: UNDIP. http://eprints.undip.ac.id/4972/

Istiqomah, Z. dan Esthi M. (2018). "Demi kurangi sampah gerakan kangpisman di masifkan.” republika.co.id. $\quad$ Diakses $\quad 27 \quad$ Mei 2020. https://www.republika.co.id/berita/nasional/daerah/18/12/10/pjj0rc335-demikurangi-sampah-gerakan-kangpisman-dimasifkan 
Pariska, Z.U. (2018). "Pesan dakwah ustad Hanan Attaki Analisis Isi Kajian Fathi 'Pegang Janji Allah’ Episode 27 September 2017 Via YouTube.” SKRIPSI. Surabaya: UIN Sunan Ampel

Raharjo. (2018). “Generasi muda berperan penting perangi sampah.” Koran-jakarta.com. Diakses 27 Mei 2020. http://www.koran-jakarta.com/generasi-muda-berperanpenting-perangi-sampah/

Widiarti, W.I. (2012). “Pengelolaan Sampah Berbasis 'Zero Waste' Skala Rumah Tangga Secara Mandiri." Jurnal Sains dan teknologi lingkungan. 4 (2) h. 101-113

Witarsa, R.G. (2019). "Perancangan Media Visual Kampanye Sosial Mulai Hidup Tanpa Sampah Plastik Sekali Pakai." SKRIPSI. Bandung: Universitas Pasundan

Yaqinah, S.N. (2019). "Implementasu Dakwah Berbasis Lingkungan Hidup di Pondok Pesantren Nurul Haramain Narmada Lombok Barat". Jurnal Al-Bayan, Media Kajian dan Pengembangan Ilmu Dakwah. 25 (1) h. 178-217 